\title{
A Retrospective View Of The IFRS' Conceptual Path And Treatment Of Fair Value Measurements In Financial Reporting
}

Stephen B. Shanklin, University of Southern Indiana, USA

Debra R. Hunter, University of Southern Indiana, USA

Craig R. Ehlen, University of Southern Indiana, USA

\begin{abstract}
International Financial Reporting Standards ("IFRS") require some assets, liabilities and equity instruments to be measured at fair value (IASB - ED/2009/5). Thus begins the Fair Value Measurement IASB 2009 Exposure Draft. The IFRS requirement for fair value reporting has actually existed since 1975, due to the adoption of pronouncement IAS 2 (IASC/IAS 2 - 1975). This standard required that Inventory be valued at "...fair value less costs to sell" for both reporting and disclosure purposes. But, as is the case in the history of many accounting standards and practice, "the devil has always been in the details." This paper explores a brief historical path of fair value accounting within the venue of international accounting standards. Because of the impending plan of convergence and harmonization, plus potential global acceptance of standards of reporting and content, both the IASB and FASB have extensively explored the relevance and reliability of fair value reporting as compared with the more traditional cost-based system. This exploration has been controversial because it goes to the very heart of the centuriesold cost-based foundation of financial accounting. In spite of the ongoing controversy of fair value versus historical cost accounting and the multiple uses and requirements of the fair value theoretical concept in IFRSs, there has been no definitive guidance on the various alternative calculations and appropriate uses of these differing representations of "fair value." As the comment period closes on a second exposure draft directed at resolving "Fair Value Measurement," this retrospective view of the international standards moves through the past standards and into the future methodology of reporting fair value. With FASB's latest exposure draft on fair value currently pending, the convergence opportunity of a more closely defined concept and its subsequent use in global practice is quite possibly at hand.
\end{abstract}

Keywords: IFRS; Fair Value Measurement

\section{INTRODUCTION}

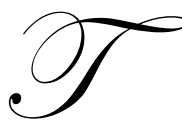

he historical cost model of financial accounting has been the general standard in the U.S. and most of the rest of the world for many years. A period of economic instability and international inflation in the early 1970s focused criticism on the accounting profession regarding the inadequacies of valuations presented by the historical cost model of financial accounting. In 1976, this discussion was elevated further by three discussion memoranda issued by FASB (FASB - memo, 1976), thus leading to a movement in the U.S. to incorporate market and/or fair value reporting in financial statements rather than continuing to use the traditional historical cost.

On the international scene, fair value found its official introduction into the standards lexicon in September, 1974 with an exposure draft (IASC, ED2/1974/9) on Inventory. This was the opening salvo in a protracted and piecemeal approach to incorporating the general concept of reporting fair values as an informative alternative to historical costs. While IAS 2 (Inventory) promoted the merits of reporting specific inventory items using fair value, 
no attempt was made to prescribe the calculation or methodology to be used to meet the standard (IASC/IAS 2 1975). The standard required a disclosure of the balance sheet item being reported at "fair value."

Following the introductory use of fair value for Inventory (IASC/IAS 2 - 1975), the use of fair value in reporting standards was later expanded into Property, Plant, and Equipment (IASC/IAS 16 - 1982); Leases (IASC/IAS 17 - 1982); Revenues (IASC/IAS 18 - 1982); Employee Benefits (IASC/IAS 19 - 1983); Accounting and Reporting by Retirement Benefit Plans (IASC/IAS 26 - 1987); Impairment of Assets (IASC/IAS 36 - 1998); Financial Instruments: Recognition and Measurement (IACS/IAS 39 - 1998); Investment Property (IASC/IAS 40 2000); and in a specialized area of reporting in Agriculture (IASC/IAS 41 - 2000). Despite the extensive list of fair value reporting requirements over the past thirty-five years, to date there has been no required or even suggested formulation presented as to an appropriate calculation or methodology for generating a fair value for meeting the financial standards. This has been a point of concern to both users and preparers of financial statements using the IASs and IFRSs for reporting.

While the inclusion of fair value accounting was helpful to users in assessing a company's "real" financial position, the incorporation of additional fair value reporting requirements for a wider spectrum of reporting purposes only added to the difficulty of interpreting the numbers presented. The IASB, and its predecessor (IASC), have openly required the use of the fair value measurement options over the historical cost-based valuation in their pronouncements. Their path of utilizing fair value measurements has paralleled the path followed by the FASB, which also has openly embraced the fair value option in its more recent pronouncements. However, neither initiative (IASB or FASB) embraced fair value in a conceptual foundation approach. Instead, each has chosen to utilize a piece-meal inclusion of fair value measures in reporting over a span of thirty-five years.

The primary shortcoming in the IASB adoption process is that while they embraced "fair value" as a reporting concept and, in many cases, as a reporting requirement, they did not issue/propose any authoritative definition for "fair value" until September, 2009 in an exposure draft specifically titled Fair Value Measurement (IASB - ED/2009/5). FASB had previously issued guidance for U.S. GAAP users in 2006 (FASB/FAS No. 157 2006). Both documents are titled "Fair Value Measurement(s)" [The FASB pronouncement using the plural form]. Most recently, IASB has issued a second exposure draft (IASB - ED/2010/7), with limited scope for comment, based upon the comments and concerns received from the first exposure draft (IASB - ED/2009/5). This second draft, titled Measurement Uncertainty Analysis Disclosure for Fair Value Measurements, reveals the ongoing problem of the users' struggles to gather relevant and comparable informational content from the fair value representational requirements previously codified.

In the International Financial Reporting Standard X, Fair Value Measurement (IASB - 2010), proposed following the comment period from ED/2009/5 and the follow-up ED/2010/7, the IASB stated their expressed reasoning and objectives for new reporting standards. The IASB felt they needed to:

- $\quad$ provide a single source of guidance for fair value measurements required/permitted by IFRSs to reduce complexity and improve consistency in the application of fair value usage

- $\quad$ specifically define fair value and provide guidance that communicates the measurement objective more clearly

- enhance fair value measurement disclosures to help financial statement users assess the valuation techniques and the inputs used by companies to develop fair value measurements

- $\quad$ continue the convergence of IFRSs and US GAAP (IASB/IFRS X - 2010).

Further, the IASB has issued a much anticipated proposed definition for "Fair Value Measurement" in the new standard. This definition is presented as a foundation point in the document and is known as "Core Principle 1:" "Fair value is the price that would be received to sell an asset or paid to transfer a liability in an orderly transaction between market participants at the measurement date" (IASB/IFRS X - 2010).

The clarification of the component parts of the definition and points of specific guidance in applying the definition went even further. The declared scope of the defined use of Fair Value "... applies to IFRSs that require fair value measurements or disclosures about fair value measurements...(IASB/IFRS X - 2010)". The two stated 
exceptions are in the case of Share-based Payment (IASB/IFRS 2 - 1975) and Leases (IASB/IAS 17 - 1982). Further clarification in the scope of use states that while the standard explains how to measure fair value, it does not require additional fair value measurement, nor does it establish valuation standards (IASB/IFRS X - 2010). Further assurance is given that future uses of fair value will not expand the measurement possibilities, but will work within the definitional framework and measurement options provided in this current pronouncement.

The fair value measurement assumes a transactional approach that occurs in "...an orderly transaction between market participants...(IASB/IFRS X - 2010)". The valuation on a transaction date does not occur under pressure/duress and thus is not a forced transaction without normal market forces and alternatives for action. This caveat assures the integrity of the word fair in establishing the value of an asset or liability.

To further provide a full description of the nature of the transfer, the Board adds a qualitative assumption to the transaction environment for fair value. "A fair value measurement assumes that the transaction to sell the asset or transfer the liability either: (a) takes place in the principal market for the asset or liability (or) (b) in the absence of a principal market, takes place in the most advantageous market for the asset or liability" (IASB/IFRS X - 2010). This qualitative requirement for the transaction places value on the marketplace's assessment of value and requires that some effort be expended to establish the principle market for such transaction. Only in the absence of an actual transaction at the measurement date for fair value reporting may an alternative be applied. The alternative measurement assumes that a transaction takes place in the principal or most advantageous market from the perspective of the holder of the asset or the party owing the liability. Thus, the test seeks the fairness of the best market transactional value that can be established for all parties involved.

Once these basic components are reached as a threshold for presenting fair value, the assets and/or liabilities are divided into financial and non-financial classes. For financial assets/liabilities, a company should utilize a qualitative hierarchy to determine the fair value to use. To value non-financial assets, the company takes another approach that seeks the fair value based upon an asset's highest and best use, but with a similar anticipation of outcome as the financial assets/liabilities.

Three alternative approaches are offered to provide valuations considered as "fair" for financial assets/liabilities. Techniques for arriving at acceptable fair values within the proposed standards should follow either a(n) (1) market approach, (2) income approach, or (3) cost approach. The market approach uses traditionally familiar market measures of identical or comparable assets or liabilities. These calculations can be quite simple with a perfect market match or they can use more sophisticated financial matrix pricing models. The income approach is a discounted valuation using present value calculations, accepted option pricing models, or a multi-period excess earnings model. The choice of the evaluation model may be more dependent on the nature of the asset/liability measured than merely a choice of three equal alternative possibilities. The cost approach usually goes by the more familiar name of current replacement cost. This approach has traditionally been used in the valuation of tangible assets, and in many cases, current assets (i.e., inventory).

When alternative valuations are available, an established hierarchy is proposed. The IFRS hierarchy has three levels. Level 1 measures have the highest position in the proposed hierarchy. Level 1 inputs are based on quoted prices available in active markets for identical (or nearly identical) assets/liabilities. Level 2 inputs are "...other than quoted prices included within Level 1 that are observable... ...either directly or indirectly" (IASB/IFRS X - 2010). Level 2 measures typically qualify as Level 1, except perhaps the active market factor may be somewhat in question. Additional detailed guidance is provided to help establish the quality of these measures within the hierarchy level so as to render the best possible Level 2 value when a Level 1 measure is not possible. Failing the ability to reach either a Level 1 or 2 position within the hierarchy, Level 3 is the lowest level for establishing a fair value within the proposed standard. Level 3 requirements include those cases when there is no observable input for the asset/liability. While the input differs, the expectation for an output is exactly the same as with Levels 1 and 2 . The measurement objective is "... an exit price from the perspective of a market participant who holds the asset or owes the liability at the measurement date (IASB/IFRS X - 2010)." With this perspective, the user of the financial statement has some assurance that, with full disclosure, the resulting valuation in the financial statements must meet the same standard for inclusion as a fair value, regardless of how (at what Level) the valuation 
was achieved. This approach is in keeping with the theoretical hierarchy presentation from FASB's Financial Accounting Concept Statement No.7 (2000).

While this stated hierarchy establishes fair values for financial assets by using market-based measures, the fair value of non-financial assets is determined using a utility-based measure. Non-financial assets' reporting of fair value centers on the premise that the valuation will be made for the "...highest and best use of the asset......that is physically possible, legally permissible, and financially feasible..." (IASB/IFRS X - 2010). The highest and best use approach requires an assessment as to whether the asset(s) can reach its highest and best use alone or in quantities of sufficient number as to advance the calculation of the fair value. While this may appear at first to be an exact opposite of the financial accounting concept of conservatism, the highest and best use measure is somewhat tempered in that it is limited, on an ongoing basis, by the marketplace participants' view of the applied value of the asset(s) in question. That aspect provides the consistent market-based view of fair value sought by financial statement users. Disclosures as to the methodology of the fair value calculations and the auditors' opinion on such presentations does provide a more moderating assurance that conservatism has not been replaced by extreme optimism in the fairness of value presented.

Current proposed provisions for presentation of fair value would not apply to Leases (IASC/IAS 17 1982), nor would it apply to Share-based Payment (IASB/IFRS 2 - 2004). No definitive guidance in these specific applications of fair value is currently provided by the IASB. Current proposed standards are also clear about the intent to use the current presentations for fair value for all future pronouncements and not to expand or call for other definitions of fair value. Essentially, this work closed the loop on fair value and will require other similar concepts to be called by different names if their definition does not fall within the proposed standards. This will allow for a much more concise discussion and uniform presentation of fair value for all stakeholders associated with financial statements prepared in accordance with IFRS.

To add further value to the IASB's definitional presentations of fair value and a more uniform use of fair value in practice, FASB also issued an exposure draft (FASB/Exposure Draft - 2010). The draft, issued as an accounting standards update, is titled Amendments for Common Fair Value Measurement and Disclosure Requirements in U.S. GAAP and IFRSs. As part of the Accounting Standards Codification project, this draft would amend and revise the codification of FASB's pronouncement of Fair Value Measurements (FASB/FAS 157 - 2006) and result in amendments to U.S. GAAP Codified Topic 820 Fair Value Measurements and Disclosures. The draft is virtually identical in content and form to the IFRS draft with the following exceptions:

1. The scope of the outcome is not the same due to the differences in applications and use of fair value requirements/options under existing GAAP and IFRS standards.

2. There are differences in the requirements and disclosures for measuring investments held by investment companies at fair value.

3. The disclosure requirements for fair value presentations differ under GAAP and IFRS for "recurring" and "non-recurring" fair value measures.

The fact that the IASB and FASB have essentially agreed on the broad definition of fair value provides the opportunity for the concept to have a better-defined usage on a global reporting basis. The immediate effect on IFRS-based reporting is that the current standards (except for those specifically excluded) will be modified to utilize the new definition of fair value in the ways prescribed in the original pronouncements or amended to reflect the definition specifically. In many cases, the current proposal provides amendment language for a listing of pronouncements individually (by citation or paragraph designation) or simply states that any reference to fair value in prior standards is now interpreted retroactively by the current definition. The resulting effect, quite simply, is that former interpretive uses of fair value must now comprehensively fall into conformity with the newly defined one. The specific IFRS standards affected are IFRS 1, IFRS 3 through IFRS 5, IAS 2, IAS 16 through 21, IAS 39, and IAS 40. 


\section{CONCLUSION}

The essence of the proposed standards by the IASB will finally address the persistently contentious issue of using fair value in financial reporting. The standards would define the expectations of how to determine fair value. That alone is a breakthrough for greater acceptance and understanding of the use of fair value in international reporting. With this proposal, the IASB has taken the leadership role in its work with FASB in the area of fair value presentation. FASB issued its current standard on Fair Value Measurements (FAS 157) in 2006, but had multiple definitions for fair value in various areas of practice or application. Current proposed revisions of FAS 157 will bring greater value to the work and leadership provided by the IASB in its advocacy for greater and more consistent use of fair value accounting in reporting. The great similarity in definition, if not exact wording and use, for fair value between the IASB and FASB marks the closing of a gap in user-based interpretive value and opens an opportunity for greater harmonization of international and U.S. GAAP; convergence on additional standards could be reached using the same approach the two groups followed to reach agreement on the fair value issue.

While there is much to appreciate in the definitional outcomes for fair value, a big gap in fair value usage still exists. One question which logically follows is "Precisely when is the new how to be used?" There are two whens that must be considered. The first is when should fair value measures be used (as opposed to other measures) in practice? The second when involves assessing the timing and value of this standard with respect to the topics matrix established for IASB/FASB work moving toward harmonization.

The IASB has now established a substantially uniform definition of fair value. IASB, in their work on fair value, has been adamant that the definitional constraints established in the forthcoming standard be the exclusive definition for fair value moving forward in all standards. By meeting in joint conference with FASB in the constructive phases of the work, before final verbiage was chosen, the likelihood of conceptual agreement with FASB's revised fair value definition was greatly enhanced. With only sparse exceptions in some semantics of application, the IASB has laid groundwork that can be seen as satisfying the FASB conceptual foundation of consistency and thus provides some general characteristics of comparability in financial reporting. With this crosspollination on standards from IASB/FASB in the development stage, the spirit of collaboration should lead to increasing levels of harmonization of IFRS and U.S. GAAP.

In a further look at the IFRS project matrix of next accounting topics under consideration, the timeline of harmonization with FASB now appears to be realistically achievable. Congruent fair value definitions provide one less obstacle in upcoming topics and provide a realistic chance that when a fair value measurement must be used, it will essentially have universal acceptance. This would be a giant step forward for global financial reporting.

\section{AUTHOR INFORMATION}

Stephen B. Shanklin, Ph.D., CPA, focuses on innovative instruction in financial accounting and issues in international business and accounting. He is currently on faculty at the University of Southern Indiana after an extended career in risk management and consulting.

Debra R. Hunter, DBA, CPA (inactive) specializes in financial and managerial accounting. She has ten years of experience in public accounting and retail accounting. She serves on a non-profit board where she is a member of the finance committee. Dr. Hunter has published three other articles in academic and professional journals. She is a member of the American Institute of Certified Public Accountants (AICPA), the Indiana CPA Society (INCPAS), and the Louisiana CPA Society (LCPAS).

Craig R. Ehlen, DBA, CPA, CFE, specializes in fraud auditing. He has twenty years of experience in public accounting and senior financial management with both large and small public companies. Dr. Ehlen also has been a director of several U.S. corporations and overseas joint ventures. Dr. Ehlen has published more than forty articles in academic and professional journals, including Auditing: A Journal of Practice \& Theory, The CPA Journal, The Journal of Occupational \& Organizational Psychology, and Fraud Magazine. The Indiana CPA Society selected Dr. Ehlen as Indiana's "Outstanding Accounting Educator" in 2001. 


\section{REFERENCES}

1. Ball, Ray. "International Financial reporting Standards (IFRS): pros and cons for investors." Accounting and Business Research, International Accounting Policy Forum. 2006.

2. Barlev, Benzion; Joshua Rene Haddad. "Harmonization, Comparability, and Fair Value Accounting." Journal of Accounting, Auditing, \& Finance. Summer 2007.

3. $\quad$ Ernst \& Young LLP, Assurance and Advisory Business Services. "U.S. GAAP v. IFRS The Basics." Fall 2007.

4. $\quad$ European Research Associates Ltd. "IASB Observer.” Joint Meeting IASB/FASB. January 2010.

5. Financial Accounting Standards Board. "Fair Value Measurements." FAS No. 157. September 2006.

6. Financial Accounting Standards Board. "Amendments for Common Fair Value Measurement and Disclosure Requirements in U.S. GAAP and IFRSs.” Exposure Draft. June 2010.

7. International Accounting Standards Board. "First Time Adoption of International Financial Reporting Standards." IFRS 1. June 2003.

8. International Accounting Standards Board. "Share Based Payment." IFRS 2. February 2004.

9. International Accounting Standards Board. "Business Combinations." IFRS 3. March 2004.

10. International Accounting Standards Board. "Insurance Contracts.” IFRS 4. March 2004.

11. International Accounting Standards Board. "Noncurrent Assets Held for Sale and Discontinued Operations." IFRS 5. March 2004.

12. International Accounting Standards Board. "Fair Value Measurement." Exposure Draft-May 2009.

13. International Accounting Standards Board. "Measurement Uncertainty Analysis Disclosure for Fair Value Measurements." Exposure Draft - July 2010.

14. International Accounting Standards Board. "Fair Value Measurement." IFRS X. August 2010: 3, 5, 6.

15. International Accounting Standards Committee. "Inventories." IAS 2. October 1975.

16. International Accounting Standards Committee. "Property, Plant and Equipment." IAS 16. March 1982.

17. International Accounting Standards Committee. "Leases." IAS 17. September 1982.

18. International Accounting Standards Committee. "Revenues." IAS 18. December 1982

19. International Accounting Standards Committee. "Employee Benefits." IAS 19. January 1983.

20. International Accounting Standards Committee. "Accounting for Government Grants and Disclosure of Government Assistance.” IAS 20. April 1983.

21. International Accounting Standards Committee. "The Effects of Changes in Foreign Exchange Rates." IAS 21. July 1983.

22. International Accounting Standards Committee. "Accounting and Reporting by Retirement Benefit Plans." IAS 26. January 1987.

23. International Accounting Standards Committee. "Impairment of Assets." IAS 36. June 1998.

24. International Accounting Standards Committee. "Financial Instruments: Recognition and Measurement." IAS 39. December 1998.

25. International Accounting Standards Committee. "Investment Property." IAS 40. April 2000.

26. International Accounting Standards Committee. "Agriculture." IAS 41. December 2000.

27. Picker, Ruth. Ernst \& Young Global Limited, "IASB Projects Guide.” May 2010.

28. PricewaterhouseCoopers LLP. "10Minutes on the Emerging Influence of IFRS.” April 2009. 